К. А. Качайло

\title{
ФУНКЦІОНУВАННЯ ІМЕННИКІВ-ДЕМІНУТИВІВ У ТЕКСТАХ ІСТОРИЧНИХ СПІВАНОК-ХРОНІК
}

\begin{abstract}
Качайло К. А. Функціонування іменників-демінутивів у текстах історичних співанок-хронік.

У статті розглянуто особливості функціонування, специфіку семантики і словотвірної структури іменників-демінутивів, використаних в українських співанкаххроніках з історичною підосновою; проаналізовано деривати, які утворені шляхом приєднання до мотивуючої основи сімнадцяти суфіксальних афіксів; визначено важливість та необхідність їх використання у фольклорному тексті.

Ключові слова: демінутив, словотвірна структура, стилістична функція.
\end{abstract}

Качайло К. А. Функционирование деминутивных имен существительных в текстах исторических спиванок-хроник.

В статье рассматриваются особенности функционирования, специфика семантики и словообразовательной структуры деминутивных имен существительных, использованных в украинских спиванках-хрониках с исторической подосновой; анализируются дериваты, образованные путем присоединения к мотивирующей основе семнадцати суффиксальных аффиксов; определяется важность и необходимость их использования в фольклорном тексте.

Ключевые слова: деминутив, словообразовательная структура, стилистическая функция.

Kachaylo K. A. Functioning of diminutive nouns in the texts of historical spivankichronicles.

The article deals with the peculiarities of functioning, the specifity of semantics and word-formative structure of diminutive nouns used in spivanki-chronicles with historical basis; analyzes derivatives formed by means of joining seventeen suffixes to motivating base; defines the importance and necessity of their usage in folklore text.

Key words: deminutyv, wordforming structure, stylistic feature. 
На сьогодні в мовознавстві існує два підходи до трактування демінутивних утворень. Прихильники першого (Ф. Ф. Фортунатов, О. І. Соболевський, О. О. Потебня, П. С. Кузнецов та інші) вважають, що форманти суб'єктивної оцінки утворюють нові слова, тому вони є словотворчими суфіксами. Представники іншого підходу (Ф. І. Буслаєв, В. В. Виноградов О. О. Шахматов, Л. В. Щерба та інші) схиляються до думки, що форманти суб'єктивної оцінки створюють відтінки значень слів i тому належать до формотворчих. У пропонованому дослідженні ми орієнтувалися на думку тих мовознавців, які вважають похідні з емотивно-оцінними формантами окремими словами, а суфіксам, які беруть участь у їхньому творенні, надають статус словотворчих.

Мета статті - з'ясувати структурно-семантичні особливості та специфіку функціонування іменників-демінутивів, які використані у співанках-хроніках з історичною підосновою.

За нашими даними, у текстах ста сорока п'яти історичних співанок-хронік зафіксовано двісті тридцять дериватів, які мають різноманітну словотвірну структуру. Зібраний фактологічний матеріал показав, що аналізовані похідні слова утворені за допомогою сімнадцяти різноманітних суфіксів. Найбільша кількість дібраних іменників-демінутивів містить у словотвірній структурі формант -к (a). Такі деривати можна представити лексико-семантичними групами: 1) назви осіб за родинними стосунками та за характерними ознаками: I чоловік на Вкраӥні на війні загинув, Та й Олену, як сирітку, навіки покинув (ОР 81); Ой холодна керниченька, лиш би ї̈ пити, Хотів бих тя, молодичко, щциро полюбити (ОР 89); 2) власні назви: Ци то правда, щуо губили Пилипка в темницич? (ОР 95); Ой і крикнув на Іванка та на Міхайлика (ОР 109); 3) найменування тварин і птахів: $A$ ж овечки важнівечки, ягнятка дрібненькі (РВ 126); Та й корови тиролєсті, телятка маленькі (РВ 126); пане-боже, море широкоє, Та би прийшло загоїти соколятко моє (ЕС 161); Стала весна наставати, зозулька кувати (ОР 84); Ти би мені передала горобчиком солі, Горобчиком солі, синичкою хліба, Тоді б ти, мила, знала, щзо в Канаді біда (ЕС 157); 4) назви рослин та їх плодів: Уродився син Олекса щее кращий від чічки (ОР 87); На калинці дві ягідці та й на сухім стеблі (ОР 108); Ой виросли на горбочку дві берізки білі (OP 115); 5) найменування частин тіла людини: Що два хлопиі, як 
голубиі, головки склонили (ОР 102); Ніжки йому зав'язали, ручки потужсили (ОР 108); Явилися Мирін Штолі та й у личку иявіти (OP 108), Ск сів Дмитрик на коника, в плай вистрільнюючи, А Анничка біле личко, слізки втираючи (ОР 111); 6) назви місцевості: $А$ єк вони Марусеньку пріч обрабували, Але вийшли на царинку та й приночували (ОР 97); Ой у моєму городечку отава зелена, Як убили в полонинці Фотюка Семена (ОР 104); Ні роботи, ні крейцера, каліков зостався, Він до рідної земельки до дому достався (ЕС 164); Віддай мені пістоліта, віддай ми рушницу, Доріжкки ми випадають попід Молдовищу (ОР 111); Раз прийшов він з буковинки, у сопілку грає, Через кілька хвилиночок Дзвінка вибігає (ОР 90); 7) найменування частини доби: Породила молоденька темненької нічки (ОР 87), $A$ він втікав через гори, попід полонини, Здогонила темна нічка його край долини (ОР 113); 8) назва посуду: А третя сестра принесла горнєтко пшениці (ОР 105); 9) абстрактна назва: Хто не знає Америку, най ся ня питає, Скільки людей тамки бідних, а дольки немає (ЕС 164).

Далі за кількістю йдуть деривати зі зменшено-пестливим значенням, що утворені за допомогою суфіксів -очк-(а) та -ик. Вони представлені такими лексико-семантичними групами: 1) назви осіб за різними характерними ознаками: Не плачте, ви дівчаточка, за нами, за нами (РВ 127); Ой ти підеш, милий, в Канаду служити, Я лишуся 3 діточками тай буду бідити (ЕС 157); як побили цісарика, з него насміяти (РВ 123); А ви, каже, гуцулики, знайте отсу дію, Що німецька сорочечка нікого не гріє (РВ 124); Ніби прийшли дохторик, щуоби лікувати (ЕС 159); Та не знати, доки би то так було тривало, Але осени одної дідика не стало (ОР 84); Та й не могла діждатися Олексика свого, Легіника найкращого, орлика гірського (ОР 85); Узяли го на корабель, перебрели річку: «Цімборики мої любі, паліте ми свічку!» (ЕС 162); та й в віконще глипнув, А на свої пушкарики ізгрізненька крикнув (ОР 109); $A$ як вийшли жсовнірики, в ряди поставали (РВ 118); Що, хлопиі плачете? Не бійтеся жсовнярики, чей не погинете! (РВ 127); 2) власні назви: Породила Оленочка темненької нічки (ОР 82); А Дзвіночка так весело зачала казати (OP 84); Чи би не час, Семеночку, гроші нам віддати? (ОР 97); Та й узели вни Дмитрочка в чуні перевезли (ОР 102); Ходім, ходім у Слітанки Юрочку шукати (ОР 113); Будь проклята Канадочко, Канадо-небого, 3 Гуцульщини задурила хлопия молодого (ЕС 160); Ой 
ходи ти, Семенику, не поживеш смерти (ОР 103); Богдай тобі, Миронику, та і твого тати, Чи ти не чув, як той казав для нас постарати? (ОР 106); Ой імили Пилипика за білі рученьки, Та узіли Пилипика до невольниченьки (ОР 94); Ск сі вибрав любчик Дмитрик понад Луковиці, Пішов голос попід колос в село до Анниці (ОР 111); Але в моїм огороді та явір зібгався; Ой імили Николика, Юрина сховався (ОР 115); 3) назви тварин та птахів: Ой зарикла у чередi коровочка бура (ОР 115); Любив пана Ромашкана коник молоденький (РВ 126); 4) найменування явищ природи: $A$ вни тої негодочки дуже си страхали (ОР 100); $A$ із тої полонини дрібний дождик крапав (РВ 119); Нараз зачав грім гриміти, дощик накрапати (ОР 87); 5) назви предметів побуту та одягу: Дали йому коновочки, по воду післали (РВ 123); А барточка Довбушева аж сі сріблом мечіт (ОР 83); Черевички йому дали , в кабатик убрали (ОР 96); 6) найменування місцевості: $A$ на панській цариночці отава зелена (ОР 99); $А$ вни пойшли ... в полониночки (ОР 106); 7) назви будівель та певних споруд: А пусти нас до хаточки, де сама ночуєш (ОР 103); Як найнявся я у пана землю обробляти, Викопав там земляночку, бо не було хати (ЕС 160); Без крейцара й із стодоли під плотик вигнали (ЕС 164); 8) назви частин тіла людини: Треба взяти срібну кулю, ярі колосочки, I срібного волосочка з мої головочки (ОР 90); Кучерики обітяли, карабін завдали (ОР 96); 9) абстрактні назви: I сталася неславочка на тій Яблоници (ОР 109); Прийшла йому на гадочку ой старенька мати (ЕС 164); Яку-сь чути новиночку, - не можна казати (ОР 106); 10) найменування грошових одиниць: Та за тії талярики тяжко бо робити (ЕС 161); В Америці красно жиє, грошики збирає (ЕС 163). Поодинокими прикладами представлені назви напоїв та їжі: Дали ж бабі-чарівниці горівочки бочку (РВ 124); Посербаєм гуслиночки та й порадимося (ОР 104); проміжку часу: Через кілька хвилиночок Дзвінка вибігає (ОР 90); музичного твору: Та не цисе співаночка, цисе правда била (РВ 126); певного виду діяльності: То там собі набивали остріжні стрільбочки (ОР 106); найменування техніки: Їде, ̈̈де машиночка, в Ужгороді стала (EC 159).

Іменники-демінутиви, які містять у словотвірній структурі суфікс -ок, в основному є назвами осіб: Не меш, синку, бідувати, будеш славу мати (ОР 82); Отак дідок поговорив, з хлопцем розійшовся (ОР 87); $A$ () К. А. Качайло, 2015. 
хто з него гонір здоймив? То панок Герлічка (ОР 108); Гой, учув ие цісаричок на свої столици, Посилає роту війська та й за Кобилицев (РВ 124); Єŭ, тото нас, товаришку, на мак порубає! (РВ 128); Ой знаю я, мій мужичку, ту шесту заповідь (ЕС 164). Серед аналізованих іменників 3 морфемою -ок наявні також найменування частини тіла людини: Ой виходит кум із шинку, n'яний, аж ся гонит, Мою жінку молоденьку попід бочки водить (ЕС 166); місцин: Пускай в дворок Марисечко! Ци сама ночуєш? (ОР 97); Ск учула та Анничка бай сісі словечка, Не уздріла густий лісок почерез слізечка (ОР 111); птахів і тварин: Летів пташок попід дашок, а той зелененький (РВ 126); А ми, мамко, так собі, як червачки слабі (ЕС 161); взуття: Проченьові молодому черевички дали (ОР 96); стану людини: Одна: «Сонок єкий снила - то не нагадаю» (ОР 100); предметів побуту: 3 тлумачками, з діточками, був то вид чудесний (ЕС 148).

Частина іменників-демінутивів утворилася за допомогою суфікса -ок шляхом другого ступеня деривації, наприклад: назви осіб: Oŭ не вийду, мій синочку, бо я дуже слаба (РВ 127); Злакомився той паночок на бразильські мілі (ЕС 152); найменування місцевості: Ой виросли на горбочку дві берізки білі (ОР 115); Ой у моӥм городочку копана криниця (РВ 119); Ой далеко у лісочку зацвіла калина. Ой mепер я на чужині нічия дитина (ЕС 160); назви частин рослини: Треба взяти срібну кулю, ярі колосочки (ОР 90); А єк собі заспіває, запіє в листочок, По всіх горах покотиться їго голосочок (ОР 83); інші назви: По всіх горах покотиться їго голосочок (ОР 83); І срібного волосочка з мої головочки (ОР 90).

Середньою активністю при творенні іменників-демінутивів, які використані у співанках-хроніках 3 історичною підосновою, характеризуються морфеми -оньк-(a), -еньк-(а) та -ечк-(a). Іменники 3 цими афіксами представляють такі лексико-семантичні групи: 1) назви осіб: Заплакали дівчатонька дрібними сльозами (ОР 96); $A$ там тоті жсовніроньки єли воювати (ОР 96); Не плач, не плач, дівчинонько, не вдавайся в тугу! (ОР 99); Не хочу я, сестриченько, сорочечку брати, Вже би мені молодому в вогонь поступати (ОР 114); 2) власні назви: Ой Канадо, Канадонько, ти великий краю, як хто спімне за Галилей, з жалю умліваю (ЕС 162); Приступила Маріченька до порогу мліло (ОР 93); Та й подай-ко, Марієчко, полотна ляннії, Бо ми мали твердий наказ від любка Марії (ОР 102); 
3) найменування птахів: $H i$, не зраджу я ніколи тебе, голубоньку (ОР 93); Ой кувала зозуленька попід крильия жовта (ОР 107); Закувала зозулечка, закувала жовта, здогонила легіників на Рокиті ровта (ОР 94); 4) назви проміжків часу та днів: Прийшла восьма годинонька, взяв я білет брати (ЕС 155); Роблю в полі я щзоднини, вже ручок не чую, Де ніченька наздогнала, там $і$ заночую (ЕС 160); Коли прийшла неділенька, взяв торбину в руки Та пішов на станцію, як герой на муки (ЕС 159); 5) найменування приміщень: Пусти ж мене до світлоньки, де сама ночуєш (ОР 111); $A$ з весілля до корчмоньки, з корчми на хрестини (ЕС 158); 6) абстрактні назви: Та узіли Пилипка до невольниченьки (ОР 94); Буду вірна лиш одному всю свою судьбоньку (ОР 93); Ой імила, ой імила, тугонька напала (ОР 115); 7) найменування частин тіла людини: Вже Олексино серденько битися не буде (ОР 94); I білою рученькою двері отворила (OP 93); 8) назви місцевості: А изи права доріжечка на Ворохту буде? (OP 99); Видумала Бразилія містечко Удіно (ЕС 152). Поодинокими прикладами представлені найменування музичного твору: Tепер сеся співанонька Леся ся скінчила (ОР 115); одягу: Дає сестра сорочечку, він не хоче брати (ОР 113); рослин: $A$ вни єго перевезли в зелене зіллєчко (ОР 102); матеріалу: Таке тяжке желізенько, не мож подоймити (ЕС 165); астрономічна назва: Ще сонечко не світило, а місяиьь не зійшов (ОР 96).

Малопродуктивними, за даними фактологічного матеріалу, при творенні іменників-демінутивів, використаних в означених фольклорних творах, виявилися суфікси -чик, -иц-(я), -цุ-, -ачк-, -ин-(а). Утворені цими морфемами деривати можна представити такими лексико-словотвірними групами: 1) назви осіб за віковими та іншими характеристиками: Ай виріс я, гарний хлопчик, при своїи родині (ЕС 157); Його, братчику, спіймали у тітки в Ростоцฺі (OP 107); Єк сі вибрав любчик Дмитрик понад Луковиці (ОР 111); Та однако ми, сестрице, смерти поживати (ОР 113); Пішов голос попід колос в село до Анниці (ОР 111); 2) найменування птахів та частин їх тіла: Ти би мені передала горобчиком солі (ЕС 157); Ой кувала зозулиця темними лісами (ОР 81); Ой рад би я крильця мати, соколом злетіти, Ой вітати жінку й матір, цілувати діти (ЕС 148); 3) назви приміщень та ï частин: Коли сів я у вагончик, помахав рукою, Ой не знав я, чи побачу вже родину свою (ЕС 159); А сам Довбуш такий файний, єк ( К. А. Качайло, 2015. 
ружа в віконці (ОР 83); 4) найменування одягу: Купив дітям чоботята, жінці - кожушину (ЕС 148); Куплю тобі черевики $i$ капелюшину (ЕС 158); 5) назви місцевості: Ой у мойм городчику отава зелена (ОР 104); Ой кувала зозуленька межи корчиками (ОР 97); 6) найменування напоїв: Старій мамі - горілчини добрую флящину (ЕС 148); А водиця студененька, лии би ї̈ пити (ОР 84). Деякі лексико-семантичні групи іменників-демінутивів представлені усього одним прикладом, наприклад: назви посуду: добрую флящину (ЕС 148); комах: Без блощиці, як москалі, нічку переспати (ЕС 162); зброї гуцула: Нi топірчик вже не пестит, в сопілку не грає (ОР 84); топонімів: Будь проклята, Канадице (ЕС 160).

Деривати 3 суфіксами -яm-(a), -унь, -ичк-(a), -yсь та -ець представляють найменшу кількість іменників-демінутивів, використаних у співанках-хроніках з історичною підосновою. Загалом ïx можна представити такими лексико-семантичними групами: 1) назви осіб за родинними стосунками: Мій татуню солоденький, коли ж вас побачу? (ЕС 165); А мамуні німа дома аж $і$ оде вчора (ЕС 166); А там д’нему старий дідусь - тож віщун - приходит (ОР 89); На Великдень чужі діти грались краманками, Іванові сиротята вмивались сльозами (ЕС 149); 2) найменування птахів: Ой ковала зозуличка, ковала, ковала, А там була молодичка, гарненька, як пава (ОР 89); 2) власні назви: Ударили дрібні дожджі із-за того плова, Зоставайся сі ти, Анничко, від мене здорова (ОР 111); 3) найменування взуття: Та щзо з того, щзо вни вбрані в нові чоботята (ЕС 149); 4) назва зброї гуцула: Подай же нам, Марусенько, тоті сороківиі, Бо ми хлопціi йа молодці, а в руках топірці (ОР 99).

Дібраний фактологічний матеріал показує, що в історичних співанках-хроніках серед іменникових форм суб'єктивної оцінки переважну більшість становлять слова, утворені за допомогою зменшено-пестливих суфіксів, бо саме через їх посередництво виражаються найбільш різноманітні відтінки експресії: співчуття, іронія, зневага, злоба, барвиста і суперечлива гама емоцій і оцінок.

Спостереження над деривацією іменників-демінутивів, використаних в українських співанках-хроніках, дозволяють зробити висновок про те, що система суфіксів, за допомогою яких творяться ці іменники, така ж, як і в загальнонародній мові та літературнонормативній. 
Досліджувані суфіксальні деривати, виявляючи певну своєрідність функціонування, вживаються не стільки для називання здрібнілих предметів, скільки для вираження позитивного суб'єктивного ставлення до них, а ще більше як засіб створення високого ступеня експресії. «Ця думка знаходить підтвердження у численних випадках утворення форм позитивної суб'єктивної оцінки від іменників 3 абстрактним та негативним значенням» [1, с. 69]. Наприклад: Хто не знає Америку, най ся ня питає, Скільки людей тамки бідних, а дольки немає (ЕС 164); Та узіли Пилипка до невольниченьки (ОР 94); Буду вірна лиш одному всю свою судьбоньку (ОР 93); Ой імила, ой імила, тугонька напала (ОР 115); I сталася неславочка на тій Яблониции (ОР 109).

Те, що іменники 3 абстрактним значенням - назви, які викликають негативні емоції (біда, горе, недоля, неволя, розлука, неслава), функціонують зі зменшувально-пестливими суфіксами $\epsilon$ характерною особливістю пісенної фольклорної мови. Таке «маркування іменникових форм, які містять у своєму значенні яскраво виражену негативну оцінку, суфіксами із пестливим значенням посилює їх емоційно-стилістичне забарвлення» [2, с. 62]. Очевидно, створюється невідповідність між негативним лексичним значенням слова i суфіксом, за допомогою якого утворився стилістично маркований дериват. На думку сучасних вчених, йдеться про так звані експресивні внутрішні контрасти, які «у межах окремого слова зумовлюються «нелогічним» зіткненням семантики негативного емоційного плану 3 пестливістю, яка забезпечується відповідними суфіксами. Ці контрасти можна назвати внутрішніми» [2, с. 63].

Оскільки співанки-хроніки - це творчість народних митців, важливо зазначити, що в кінці майже кожного такого твору є вказівка на автора: А хто сисю співаночку Дмитреєві зложив? Але Федір таки Химчак, богдай же він прожив! Можливо, саме жанровою особливістю такого фольклорного твору зумовлене часте повторення слів співанка, співаночка: Ти лиш вийшла з Путилова співанка новенька (РВ 117); Ой ковала зозулиця, на вітер си здула, Та не циисе співаночка, ичисе правда била (РВ 126); Тепер сеся співанонька Леся ся скінчила (ОР 115); Йа леж бо та співаночка та й нова каплиия, До Відної си збирає Лук'ян Кобилиия (РВ 117). Цікаво, що у процесі опису якоїсь події або на завершення такого твору використовується () К. А. Качайло, 2015. 
зменшено-пестлива назва птаха, причому лексема зозуля має найрізноманітніші демінутивні форми, які відрізняються суфіксами: $A$ там в лісі, на ялині, сова застогнала Та зозулька в буковині сумно заковала (ОР 86); Ой ковала зозуличка темними лісами, Була колись тяжка війна з польськими панами (ОР 87); Ой кувала зозуленька межи корчиками, Вони Футюка Семена з собов підкликали (ОР 97); Закувала зозулечка, закувала жовта, здогонила легіників на Рокиті ровта (ОР 94); Ой ковала зозулиця та й буде кувати, Глянув вішунн на Довбуша та й зачав казати (ОР 87). Очевидно, цей образ використовується як застереження або привертання уваги слухачів до особливо важливих місць хронікального повідомлення.

Яскравою ознакою мови аналізованих співанок-хронік $\epsilon$ використання пестливих суфіксальних утворень від антропонімів: Богдай тобі, Миронику, та і твого тати, Чи ти не чув, як той казав для нас постарати? (ОР 106); Породила Оленочка темненької нічки Олексика молодого, кращуого від чічки (ОР 82); Єк сі вибрав любчик Дмитрик понад Луковиці, Пішов голос попід колос в село до Анниці (ОР 111); Та вбив єго Мочернячок з срібної рушниці (ОР 102); Утікав, тікав Штолючок та й зашумів листом, Та не сам він туда тікав, тікав з товариством (ОР 107).

В українському пісенному фольклорі часто словотвірна структура здрібніло-пестливих іменників узгоджується 3 ритмікою, мелодією твору, як показують результати дослідження, у співанках-хроніках також: Oй $і$ крикнув на Іванка та на Міхайлика: «Що я там, братчики, убив хло за легіника!? (ОР 109); Та щуо з того, щуо вни вбрані в нові чоботята, Коли вони ся зостали круглі сиротята (ЕС 149); Та кувала зозуличка сивенька, маленька, Ти лич вийшла $з$ Путилова співанка новенька (РВ 117).

Отже, вивчення словотвірної структури іменників-демінутивів та спостереження над використанням їх у співанках-хроніках 3 історичною підосновою, показує, що слова, які утворені різними пестливими суфіксами, виконують у аналізованому тексті специфічну стилістичну функцію, надаючи йому більшої виразності та образності.

\section{Література}

1. Волощук Р. Г. Особливості творення іменників із значенням зменшеностіпестливості в українських народних ліричних піснях / Р. Г. Волощук // Питання словотвору i граматичної структури української мови : зб. наук. статей. - 
Дніпропетровськ, 1976. - С. 69.

2. Журавльова Н. М. Емоційно-експресивне суфіксальне словотворення іменників у мові українських народних ліричних пісень / Н. М. Журавльова // Дослідження 3 словотвору та лексикології. - К. : Вища школа, 1985. - С. 61-64.

\section{Умовні скорочення використаних джерел}

ЕС - Еміграція селян з Галичини, Буковини, Поділля та Закарпаття / Співанкихроніки з історичною підосновою // Співанки-хроніки. Новини / [Упоряд. О. І. Дей, С. Й. Грица]. - К. : Наукова думка, 1972. - С. 146-167.

OP - Опришківський рух в Карпатах / Співанки-хроніки з історичною підосновою // Співанки-хроніки. Новини / [Упоряд. О. І. Дей, С. Й. Грица]. - К. : Наукова думка, 1972. - С. 81-115.

PB - Революційні виступи на Буковині в 40-х роках XIX ст. / Співанки-хроніки 3 історичною підосновою // Співанки-хроніки. Новини / [Упоряд. О. І. Дей, С. Й. Грица]. - К. : Наукова думка, 1972. - С. 116-135.

Стаття надійшла до редакиії 15.03.2015 p. 